\title{
Reading and Writing Problem among B40 Students in Malay Language Learning
}

\author{
Zamri Mahamod', Rohaida Mazlan², Norziah Amin³, Mohd Zaki Abd. Rahman³ \\ ${ }^{1}$ Faculty of Education, Universiti Kebangsaan Malaysia, Bangi, Selangor, Malaysia \\ ${ }^{2}$ Sungai Ramai Secondary School, Kajang, Selangor, Malaysia \\ ${ }^{3,4}$ Hulu Langat District Education Office, Kajang, Selangor, Malaysia
}

Article History:Received:11 January 2021; Accepted: 27 February 2021; Published online: 5 April 2021

\begin{abstract}
The study aims to identify the problems faced by among B40 students in reading and writing skills. This case study is conducted on 16 students from families that do not know B40 and substandard reading and writing in Malay Language. A total of 5 B40 Malay students, 7 B40 Chinese students and 4 B40 Indian students selected as study participants. All these students study in form 1 in two national secondary schools namely as SMKA and SMKB in Hulu Langat district, Kajang, Selangor. 8 B40 students from SMKA and 8 B40 students from SMKB. Structured interviews are used as a data collection tool. Interview data were analyzed narratively where the themes found were based on the analyzed transcripts. The findings of the study show that the main reading problem of B40 students is that they do not know how to read and do not understand what is being read. As for writing problems, B40 students do not know what is written. B40 Chinese students is the weakest students in reading and writing, followed by B40 Indian andB40 Malay students. Through the findings of this study, it can be concluded that the problem of reading and writing among B40 students is an issue that needs to be addressed by teachers, MOE and parents.
\end{abstract}

Keywords: Reading problem, writing problem, B40 students, Malay Language learning.

\section{INRODUCTION}

The issue of families earning below RM3,860.00 is the focus of the present government. Almost $40 \%$ of The Malaysian population is made up of households with monthly income under the poverty line income (Jabatan Perangkaan Malaysia 2017). As these groups/families of B40 are averagely low-income families, this poverty factor also negatively affects the contents of the B40 family, especially in their children in the aspects of residence, eating drinks, clothing and so on, including in terms of education. These families/parents of B40 have no education/lack of education/educated up to secondary schools only. Their daily lives are busy seeking sustenance until some of them neglect the welfare of children in terms of education. They/B40 families handed over their children to schools and teachers to educate their children. The study conducted by Nor Hamizah (2016) found that the socioeconomic factors of the low group/B40 family led the group/family to provide basic facilities for their children such as life/education insurance, quality education and so on. This indirectly affects children in learning such as weakness in lessons, still weak/failing to read and write well.

Economic problems between the group/family B40 cannot provide good education for their children such as tuition and purchase of educational aid materials. All parents' income is more about supporting family content and multi-bill payments for the sake of survival. As a result, B40 parents do not pay attention to their children, including in the question of education. B40 parents prioritize the economic aspects than their children's education factors. Studies by Zarinah et al. (2018) found that most parents from B40 families prioritize economic aspects than aspects such as their children's education and welfare. As a result, their children are neglected at home. Parents do not care whether their children can already read or write or not. The study, conducted by Celinea and Zamri (2018) among Bidayuh ethnic students, found that almost $75 \%$ of Bidayuh students were still less than satisfying their reading skills levels. As most of these Bidayuh students come from B40 families, it can be said that reading problems are a major problem among students from B40 families. Tamam et al. (2011), Abdul Rasid (2011), and Celinea (2018) argue that most students with reading problems and affected their academic achievements came from low-income families with no awareness of the importance of reading.

The same goes for writing skills. Students from B40 families are also on average faced problems in writing skills. The study conducted by Abdul Rasid and Zulkafli (2018), Abdul Rasid et al. (2012), Abdul Rasid (2012), Yahya and Dk. Suzanawaty (2014) showed primary school students were still having problems mastering good writing skills. Most of the students studied were rural students and from low- and middle-income families. Due to the unsatisfactory and moderate achievement of writing skills, it directly affects the achievement of students in learning Malay Language. According to Abdul Rasid (2011), the problem of writing faced by rural students has greatly influenced the achievement of students in writing Malay Language skills.

The study of reading skills and writing students from B40 families specifically has never been studied in the context of Malay Language education. Most studies of the level of mastery of reading and writing skills as well as problems faced by students are more general in nature. Although study respondents referred to primary school students, rural students, but pupil backgrounds such as those from B40 families or so on have never been studied.Hence, this study aims to examine how students from B40 families in Hulu Langat district on the level 
of mastery of reading and writing skills as well as the problems faced by students from the B40 family from the perspective of students, teachers and parents.

\section{OBJECTIVE OF THE STUDY}

The mastery of reading and writing skills is one of the key elements of KSSM Malay Language. The objective of KSSM Malay Language is to equip students with speaking competencies and can communicate to meet their needs, acquire knowledge, skills, information, values and ideas and social relationships in everyday life. Hence, the objective of this study is to find out the problem of reading and writing faced by B40 students of Malays, Chinese and Indians.

\section{RESEACRH METHODOLOGY}

The study used the design of the case study, namely the study of one multi-place case (single case multiple site) (Yin 2012; Cresswell 2008). One case refers to the case of students who do not know or less smoothly read and write Malay by students from B40 families. These students are form 1 students identified in two national secondary schools (SMK) in hulu Langat district. Various places refer to school locations that are the place of study data collection. Hence, researchers identified two SMK that many students from B40 families who did not know reading and writing in Malay. Two of the schools were identified from the Hulu Langat District Education Office (PPD Hulu Langat), Kajang, Selangor, Malaysia.

The study used the design of case studies conducted using a qualitative approach. In this study, case studies were conducted in various places to find out the causes and problems that caused students from B40 families to be unable to read and write. This case study used the method of one case of various places as the study involved more than one school (Yin 2012; Merriam 2001). In this study, the cases studied were problems reading and writing Malay Language. Various places refer to two SMKs in Hulu Langat district which identified many multiracial students from B40 families who did not know reading and writing in Malay Language.

The study participants in this case study consisted of students from B40 families who did not know and were less smooth reading. The B40 students are studying on form 1. These students are selected at random easily with the help of Malay Language teachers and through screening tests. The number of students involved in the study is shown in Table 1. Based on the schedule, the number of B40 family students who did not know the reading and writing in SMKA for chinese B40 students and 4 indian B40 students. There are no B40 students of the Malays who do not know the reading and writing. Meanwhile in SMKB, the total number of B40 family students interviewed was 8, 5 Malay B40 students and 3 Chinese B40 students. There are no Indian B40 students who cannot read and write at SMKB. In total, 16 students who did not know or less smoothly read and wrote the B40 family were used as participants.

TABLE 1: Total number of form 1 students from B40 families who do not know/ read and write in Malay Language

\begin{tabular}{ccccc}
\hline Category School & Malay & $\begin{array}{c}\text { Race } \\
\text { Chinese }\end{array}$ & Indian & Total \\
\hline SMKA & - & 4 & 4 & 8 \\
SMKB & 5 & 3 & - & 8 \\
\hline Total & $\mathbf{5}$ & $\mathbf{7}$ & $\mathbf{4}$ & $\mathbf{1 6}$ \\
\hline
\end{tabular}

Case studies of one of these various places use interview data as primary data, and Reading Tests and Writing Tests as support data.Interview Question: An interview is the main data in the study. The structured interview was conducted against form 1 students from B40 families who had reading and writing skills problems in Malay Language. Questions relating to: (i) the background of B40 students, (ii) how students create a Malay Language environment, (iii) how students build confidence using Malay Language, and (iv) and how students build selfdevelopment and learning.

Reading Test: To find out the level of reading students from B40 families who do not know reading, reading text material is provided to test the level of readability of these students when reading quotes in Malay Language. The reading text is entitled: Teenagers and Personal Hygiene (refer to Appendix A) this is used to find out if the students of the B40 family can inherently cannot read or they have trouble reading. After reading the reading text, the students asked to answer the understanding question. The purpose of answering the question of understanding is to: (i) identify the level of understanding of the students' reading skills, and (ii) knowing whether or not the students know or not what they read. Three questions should be answered by the students from the B40 family after reading the text. By answering the three questions, researchers were able to know the level of understanding of students based on the scale of understanding and reading scale referred to from Malaysia Ministry of Education (Kementerian Pendidikan Malaysia-KPM2019).

Writing Test: A written test is just like a reading test. Written tests are tested to students who do not know or have trouble reading. Written tests were given after they were tested with reading tests. Students are asked to write a short essence with a total number of words between 50 to 80 words. The short ession title is: I'm a pair of 
School Shoes (refer to Appendix B). To help these students write easily, researchers have prepared a frame for the composition to make it easier for students to write. The scale of written tests is based on the scale developed by KPM (2019).

Data analyst is a process for updating, structured and giving meaning to the data collected (Cresswell 2008; Merriam 2001). Therefore, the data obtained can be maintained for the purpose of being stored, used or set aside if it does not meet the requirements of the question. In this study, data analysts began from the early stages, starting from the first observation. The data evaluation process occurs continuously for each data collection technique used. This continuous data analyst aims to launch and simplify the data collection process. A wellmanaged data situation helps the overall data management process.

The data analysis procedure involves multiple ratings. Marshall and Rossman (2006) explained that the ranking consists of managing data, forming categories, themes and shapes, coding data, validating and so on writing reports. Ary et al. (2006) also proposed several steps that are analyzing data habits by reading repeatedly, collecting data, identify categories and theme formation, implementing the process of coding, categories, themes, themes or sub themes, authorizing data in the form of a theme tree, interpreting data and writing reports. In this study, the procedure of data analysis was done manually.

The use of triangulation methods can help address any problems that arise in verification because the problem can be identified or detected early. Even the quality of offensiveness through this method is believed to be higher than the use of only one study tool (Chua 2014). Two types of triangulation were conducted in this study, namely triangulation of data collection methods and data analytical tringulation. Three methods of data acquisition are used (interviews, reading tests and written tests) can provide a variety of evidence against the problems studied. Triangulation of these three different sources of information is used to form categories or themes in the study. The process manually determines themes based on interview questions against study participants.

\section{FINDINGS}

\section{Student Demographics B40}

In this study, 16 form 1 students from two national secondary schools in hulu Langat district were used as study participants. A total of 8 students from SMKA and 8 students from SMKB. All 16 students were identified by The Malay language teachers teaching those who could not read and write. All these students come from B40 families, whose parents are low-income below RM3500 thousand per month household income.

The results of interviews of all 16 B40 students in SMKA and SMKB, self-profile of all students' study participants ( SSP) can be filled in Table 2. Based on Table 2, the majority of B4 students who cannot read are male students, i.e. 15, while only 1 female B40 pupil cannot read in both study locations. This means that the problem of reading and writing is a male pupil compared to a female pupil. A total of 5 Malay B40 students were followed by Chinese B40 students and 4 Indian B40 students.

Most of them have siblings between 3 to 5 people. A total of 12 out of 16 people lived with parents. Only 2 people live with a mother or father (divorced parents), 1 person sitting with a grandmother/grandfather and 1 person living in the Orphanage Welfare Centre. The majority of them go to school either delivered by parents or by bus/van. What is espousing is that half of these B40 students face disciplinary problems in schools. When interviewed, the SSP acknowledged their disciplinary problems and was acknowledged or certified by the Malay Language teacher (PKG) who was interviewed. In other words, all 16 B40 students have different backgrounds with each other.

TABLE 2: Details of student study participants' personal profiles

\begin{tabular}{|c|c|c|c|c|c|c|c|c|c|c|c|c|c|c|c|c|c|c|}
\hline \multirow{4}{*}{$\begin{array}{l}\mathbf{N} \\
\mathbf{0}\end{array}$} & \multirow{4}{*}{ Self Profile SSP } & \multicolumn{16}{|c|}{ Student Study Participants (SSP) } & \multirow{4}{*}{$\begin{array}{c}\text { Tot } \\
\text { al }\end{array}$} \\
\hline & & \multicolumn{8}{|c|}{ SMK A } & \multicolumn{8}{|c|}{ SMK B } & \\
\hline & & $\mathbf{0}$ & $\mathbf{0}$ & $\mathbf{0}$ & $\mathbf{0}$ & $\mathbf{0}$ & $\mathbf{0}$ & $\mathbf{0}$ & $\mathbf{0}$ & $\mathbf{0}$ & 1 & 1 & 1 & 1 & 1 & 1 & 1 & \\
\hline & & 1 & 2 & 3 & 4 & 5 & 6 & 7 & 8 & 9 & $\mathbf{0}$ & 1 & 2 & 3 & 4 & 5 & 6 & \\
\hline \multirow[t]{3}{*}{1} & \multicolumn{17}{|l|}{ Gender } & \\
\hline & Male & 1 & I & & I & I & I & I & I & I & I & l & l & I & I & I & I & 15 \\
\hline & Female & & & I & & & & & & & & & & & & & & 1 \\
\hline \multirow[t]{4}{*}{2} & \multicolumn{18}{|l|}{ Race } \\
\hline & Malay & & & & & & & & & I & I & I & I & & & & I & 5 \\
\hline & Chines & / & / & / & / & & & & & & & & & l & I & l & & 7 \\
\hline & Indian & & & & & I & I & I & I & & & & & & & & & 4 \\
\hline \multirow[t]{2}{*}{3} & \multicolumn{17}{|l|}{ Where to live } & \\
\hline & $\begin{array}{ll}\bullet & \text { Sungai } \\
\text { Chua } & \end{array}$ & / & & & / & & & I & I & & & & & & & & & 4 \\
\hline
\end{tabular}




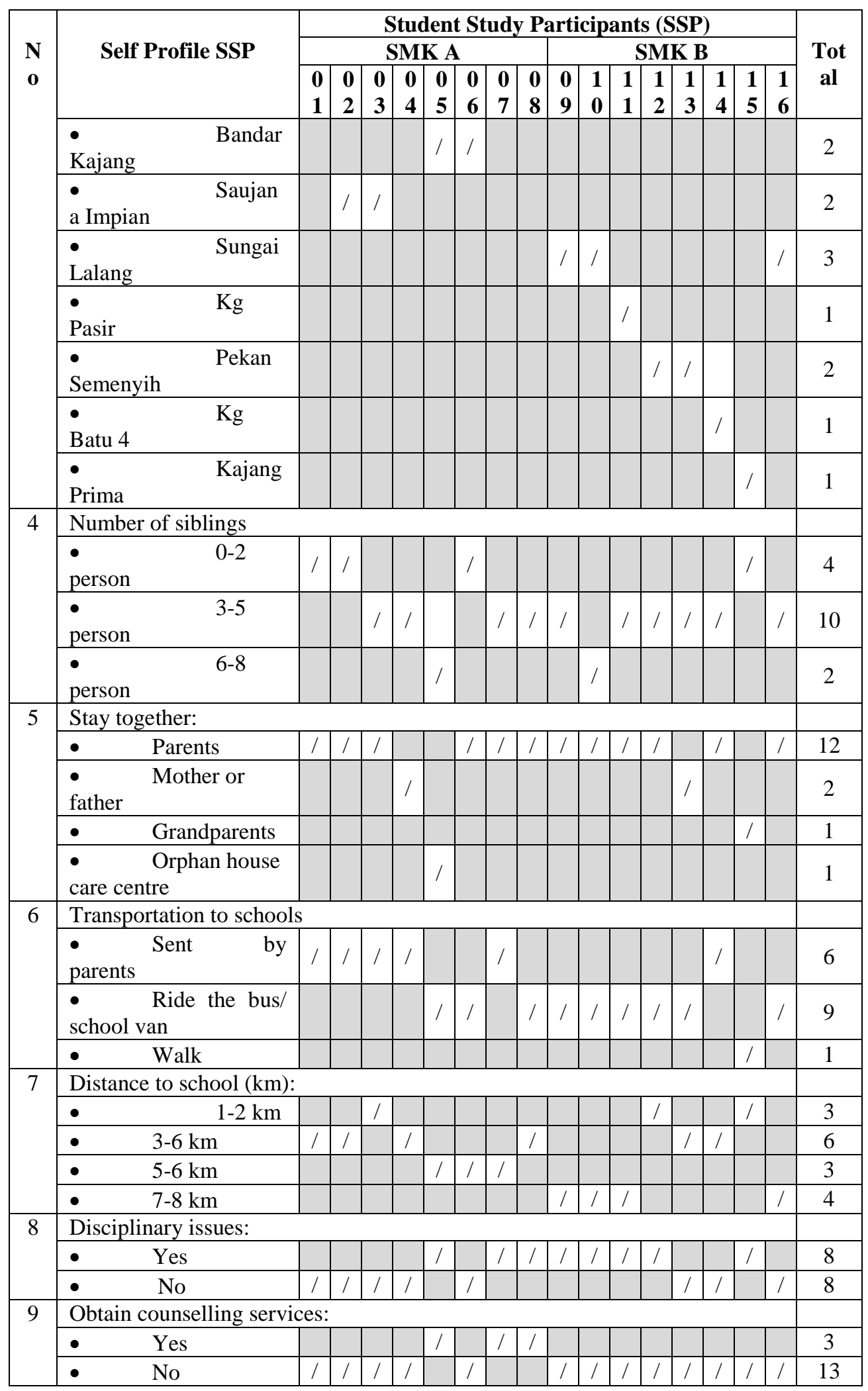

Problems Reading and Writing B40 Students in Malay Language Learning

This section discusses the question: What are the problems faced by $B 40$ students of various races in reading and writing Malay Language?

To find out the problems faced by B40 students of various races, interviews were conducted. These B40 students have been identified in two of SMK's locations, namely SMKA and SMKB. Both SMKs are located in PPD Hulu Langat, Kajang. After obtaining a letter of authorization from the parents of B40 students to enable interview sessions to be conducted. The interview question is divided into three main themes, namely: (i) creating a Malay Language environment, (ii) building confidence to use The Malay Language, and (iii) involvement in self-development and education. All three themes ask B40 students' opinions about the problems 
they face in reading and writing. Thus, 8 B40 students from SMKA and 8 B40 students from SMKB who did not know read and wrote were selected as study participants. Each student will be given the code as a Student Study Participant (SSP) 01 or SSP01 until SSP16 as shown in Table 3.

\section{Creating a Malay Language Environment}

In creating a good Malay Language environment, it started a lot from the attitude of B40 students towards Malay Language. Through interviews conducted against the 16 B40 SSP, 8 SSP favoured and interested in learning Malay Language, while the 8 SSP B40 did not favour Malay Language subjects. Most of the people who did not like Malay Language were B40 Chinese students. They excuse that:

1. Malay Language subjects are difficult to understand.

2. Cannot speak Malay Language well.

3. Cannot write Malay well.

4. Malay and Indian friends used words of tiredity in Malay Language.

Four reasons did not favour this to be said by the Chinese B40 students, namely SSP02, SSP03, SSP04, SSP012, SSP13 and SSP14. Only SSP01 loves learning and favouring Malay Language subjects. The reason for not favouring the Malays of the B40 Chinese students can be referred to the following interviews:

Throughout studying Malay Language subjects, do you favour these subjects? I don't like learning Malay Language subjects. Why don't you favour? I don't like these subjects because I can't have Malay Language well and smoothly. If I could speak Malay Language maybe I'd favour this language a little bit. Are you comfortable speaking Malay Language? I am very uncomfortable speaking Malay Language. (SSP02/TB/Line 1-6)

Throughout studying Malay Language subjects, do you favour these subjects? I don't favour Malay Language subjects. Why would you favour favourites? I don't like Malay Language subjects because I don't understand. (SSP03/TB/Line 1-4)

Throughout studying Malay Language subjects, do you favour these subjects? I am less interested in Malay Language subjects than Chinese subjects. Why don't you favour it? These Malay Language subjects are hard to understand and I am not good at speaking in Malay Language. (SSP13/TB/Line 1-5)

Based on three examples of interviews with Chinese B40 students, it is clear that weaknesses in reading skills and writing a lot due to their attitude that do not favour Malay Language lessons. The attitude of not favouring or dislike of learning the Malay Language has to do with:

1. Cannot speak Malay Language well and smoothly.

2. It is uncomfortable to speak Malay Language at home or outside the classroom.

3. Malay Language is difficult to understand and learn.

In contrast to B40 Indian students who were conducted interviews, all four participants of the study (SSP05, SSP06, SSP07 and SSP08) favoured and loved learning Malay Language. B40 Indian students favour Malays because:

1. Use/speak Malay Language daily.

2. Malay Language subjects are easy to understand and learn.

3. Many watched Malay Language speaking television broadcasts.

Throughout studying Malay Language subjects, do you favour these subjects? I love Malay subjects. Why are you favourite? Because of the days I speak Malay Language at school. (SSP05/TB/Line 1-3)

Throughout studying Malay Language subjects, do you favour these subjects? I favour Malay subjects. Why are you favourite? I love Malay Language subjects because it's easy for me to understand while reading and watching television. (SSP06/TM/Line 1-4)

TABLE 3: Creating a Malay Language environment that helps master reading and writing B40 students

\begin{tabular}{|c|c|c|c|c|c|c|c|c|c|c|c|c|c|c|c|c|c|c|}
\hline \multirow[t]{4}{*}{ No } & \multirow{4}{*}{$\begin{array}{c}\text { Creating a Malay } \\
\text { Language Environment }\end{array}$} & \multicolumn{16}{|c|}{ Student Study Participants (SSP) } & \multirow{4}{*}{ Total } \\
\hline & & \multicolumn{8}{|c|}{ SMKA } & \multicolumn{8}{|c|}{ SMKB } & \\
\hline & & & $\mathbf{0}$ & $\mathbf{0}$ & $\mathbf{0}$ & $\mathbf{0}$ & $\mathbf{0}$ & 0 & 0 & 0 & 1 & 1 & 1 & 1 & 1 & 1 & 1 & \\
\hline & & & 2 & 3 & 4 & 5 & 6 & 7 & 8 & 9 & $\mathbf{0}$ & 1 & 2 & 3 & 4 & 5 & 6 & \\
\hline \multirow[t]{2}{*}{1} & \multicolumn{17}{|c|}{ Favour Malay Language subjects: } & \\
\hline & - $\quad$ Yes & 1 & $\mathrm{x}$ & $\mathrm{x}$ & $\mathrm{X}$ & / & / & / & / & / & $\mathrm{x}$ & $\mathrm{X}$ & / & $\mathrm{x}$ & $\mathrm{x}$ & $\mathrm{x}$ & / & 8 \\
\hline
\end{tabular}




\begin{tabular}{|c|c|c|c|c|c|c|c|c|c|c|c|c|c|c|c|c|c|c|}
\hline \multirow[t]{5}{*}{ No } & \multirow{4}{*}{$\begin{array}{c}\text { Creating a Malay } \\
\text { Language Environment }\end{array}$} & \multicolumn{16}{|c|}{ Student Study Participants (SSP) } & \multirow{4}{*}{ Total } \\
\hline & & \multicolumn{8}{|c|}{\begin{tabular}{l|l} 
SMKA \\
\end{tabular}} & \multicolumn{8}{|c|}{ SMKB } & \\
\hline & & $\mathbf{0}$ & $\mathbf{0}$ & $\mathbf{0}$ & $\mathbf{0}$ & $\mathbf{0}$ & $\mathbf{0}$ & $\mathbf{0}$ & $\mathbf{0}$ & $\mathbf{0}$ & 1 & $\mathbf{1}$ & 1 & $\mathbf{1}$ & $\mathbf{1}$ & 1 & 1 & \\
\hline & & 1 & 2 & 3 & 4 & 5 & 6 & 7 & 8 & 9 & $\mathbf{0}$ & $\mathbf{1}$ & 2 & 3 & 4 & 5 & 6 & \\
\hline & No & $\mathrm{x}$ & / & / & / & $\mathrm{x}$ & $\mathrm{x}$ & $\mathrm{x}$ & $\mathrm{x}$ & $\mathrm{x}$ & / & I & $\mathrm{x}$ & l & l & I & $\mathrm{x}$ & 8 \\
\hline \multirow[t]{5}{*}{2} & \multicolumn{17}{|c|}{ Reasons for favouring Malay Language subjects: } & \\
\hline & $\begin{array}{l}\text { - Malay } \\
\text { Language subjects are easy } \\
\text { to understand and learn. }\end{array}$ & $\mathrm{x}$ & $\mathrm{x}$ & $\mathrm{x}$ & $\mathrm{x}$ & $\mathrm{x}$ & / & / & / & / & $\mathrm{x}$ & $\mathrm{x}$ & / & $\mathrm{x}$ & $\mathrm{x}$ & $\mathrm{x}$ & / & 6 \\
\hline & $\begin{array}{l}\text { I'm easy to } \\
\text { speak Malay Language }\end{array}$ & $\mathrm{x}$ & $\mathrm{x}$ & $\mathrm{x}$ & $\mathrm{x}$ & / & / & $\mathrm{x}$ & $\mathrm{x}$ & / & $\mathrm{x}$ & $\mathrm{x}$ & / & $\mathrm{x}$ & $\mathrm{x}$ & $\mathrm{x}$ & / & 5 \\
\hline & $\begin{array}{l}\text { Forced to } \\
\text { love this subject for the } \\
\text { purposes of studying } \\
\text { abroad }\end{array}$ & / & $\mathrm{x}$ & $\mathrm{x}$ & $\mathrm{x}$ & $\mathrm{x}$ & $\mathrm{x}$ & $\mathrm{x}$ & $\mathrm{x}$ & $\mathrm{x}$ & $\mathrm{x}$ & $\mathrm{x}$ & $\mathrm{x}$ & $\mathrm{x}$ & $\mathrm{x}$ & $\mathrm{x}$ & $\mathrm{x}$ & 1 \\
\hline & $\begin{array}{l}\text { - These } \\
\text { subject teachers are not } \\
\text { fierce. }\end{array}$ & $\mathrm{x}$ & $\mathrm{x}$ & $\mathrm{x}$ & $\mathrm{x}$ & $\mathrm{x}$ & $\mathrm{x}$ & $\mathrm{x}$ & $\mathrm{x}$ & / & $\mathrm{x}$ & $\mathrm{x}$ & $\mathrm{x}$ & $\mathrm{x}$ & $\mathrm{x}$ & $\mathrm{x}$ & $\mathrm{x}$ & 1 \\
\hline \multirow[t]{5}{*}{3} & \multicolumn{17}{|c|}{ Reasons not to favour Malay Language subjects } & \\
\hline & $\begin{array}{l}\text { - These } \\
\text { subjects are hard to } \\
\text { understand. }\end{array}$ & $\mathrm{x}$ & / & / & / & $\mathrm{x}$ & $\mathrm{x}$ & $\mathrm{x}$ & $\mathrm{x}$ & $x$ & I & / & $\mathrm{X}$ & I & I & I & $\mathrm{X}$ & 8 \\
\hline & $\begin{array}{l}\text { - I can't } \\
\text { speak Malay Language } \\
\text { well. }\end{array}$ & $\mathrm{x}$ & I & I & I & $\mathrm{x}$ & $\mathrm{X}$ & $\mathrm{X}$ & $\mathrm{X}$ & $\mathrm{X}$ & $\mathrm{x}$ & $\mathrm{X}$ & $\mathrm{X}$ & / & I & $\mathrm{X}$ & $\mathrm{x}$ & 5 \\
\hline & $\begin{array}{l}\text { I can't read } \\
\text { Malay Language writing } \\
\text { well. }\end{array}$ & $\mathrm{x}$ & I & I & I & $\mathrm{x}$ & $\mathrm{x}$ & $\mathrm{X}$ & $\mathrm{x}$ & $\mathrm{x}$ & I & I & $\mathrm{X}$ & I & I & I & $\mathrm{X}$ & 8 \\
\hline & $\begin{array}{l}\text { Malay and } \\
\text { Indian friends always use } \\
\text { dirty words in Malay } \\
\text { Language. }\end{array}$ & $\mathrm{x}$ & $\mathrm{x}$ & $\mathrm{X}$ & I & $\mathrm{X}$ & $\mathrm{x}$ & $\mathrm{X}$ & $\mathrm{x}$ & $\mathrm{x}$ & $\mathrm{x}$ & $\mathrm{x}$ & $\mathrm{X}$ & $\mathrm{X}$ & $\mathrm{X}$ & $\mathrm{X}$ & $\mathrm{X}$ & 1 \\
\hline \multirow[t]{4}{*}{4} & \multicolumn{17}{|c|}{ Always speak Malay Language: } & \\
\hline & - $\quad$ At home & 1 & $\mathrm{x}$ & $\mathrm{x}$ & $\mathrm{x}$ & $\mathrm{x}$ & $\mathrm{x}$ & $\mathrm{x}$ & $\mathrm{x}$ & 1 & 1 & 1 & 1 & $\mathrm{x}$ & $\mathrm{x}$ & $\mathrm{x}$ & 1 & 6 \\
\hline & In the class & l & I & I & I & I & I & I & I & I & I & I & I & I & I & I & I & 16 \\
\hline & $\begin{array}{ll}- & \text { Outsideclas } \\
\mathrm{s} & \\
\end{array}$ & I & $\mathrm{x}$ & $\mathrm{x}$ & $\mathrm{x}$ & / & I & $\mathrm{x}$ & $\mathrm{x}$ & l & l & l & / & l & $\mathrm{x}$ & $\mathrm{x}$ & l & 9 \\
\hline \multirow[t]{3}{*}{5} & \multicolumn{17}{|c|}{ Parents prohibit speaking Malay Language at home: } & \\
\hline & - $\quad$ Yes & $\mathrm{x}$ & l & $\mathrm{x}$ & $\mathrm{x}$ & $\mathrm{x}$ & $\mathrm{x}$ & $\mathrm{x}$ & $\mathrm{x}$ & $\mathrm{x}$ & $\mathrm{x}$ & $\mathrm{X}$ & $\mathrm{x}$ & I & I & I & $\mathrm{x}$ & 4 \\
\hline & • $\quad \mathrm{No}$ & / & $\mathrm{x}$ & I & / & / & / & / & / & $/$ & $/$ & / & l & $\mathrm{x}$ & $\mathrm{x}$ & $\mathrm{x}$ & / & 12 \\
\hline \multirow[t]{5}{*}{6} & \multicolumn{17}{|c|}{ With whom you always speak Malay Language: } & \\
\hline & - $\quad$ Same-race teacher. & $\mathrm{x}$ & $\mathrm{x}$ & $\mathrm{x}$ & $\mathrm{x}$ & $\mathrm{x}$ & $\mathrm{x}$ & $\mathrm{x}$ & $\mathrm{x}$ & I & l & I & I & $\mathrm{x}$ & $\mathrm{x}$ & $\mathrm{x}$ & l & 5 \\
\hline & $\begin{array}{l}\text { Teachers of } \\
\text { different races. }\end{array}$ & / & / & / & / & / & l & / & / & / & l & / & / & l & / & / & / & 16 \\
\hline & $\begin{array}{l}\text { - Equal friends of } \\
\text { the nation. }\end{array}$ & $\mathrm{x}$ & $\mathrm{x}$ & $\mathrm{x}$ & $\mathrm{X}$ & $\mathrm{X}$ & $\mathrm{x}$ & $\mathrm{X}$ & $\mathrm{x}$ & I & I & I & I & $\mathrm{x}$ & $\mathrm{X}$ & $\mathrm{X}$ & I & 5 \\
\hline & $\begin{array}{l}\text { Different friends } \\
\text { of the race. }\end{array}$ & I & $\mathrm{X}$ & I & I & I & I & I & I & I & I & I & I & I & I & I & I & 15 \\
\hline \multirow[t]{5}{*}{7} & \multicolumn{17}{|c|}{ How do parents do to help master Malay Language subjects: } & \\
\hline & $\begin{array}{l}\text { Parents advise to } \\
\text { study hard for these } \\
\text { subjects. }\end{array}$ & / & / & l & $\mathrm{x}$ & $\mathrm{x}$ & I & $\mathrm{x}$ & $\mathrm{x}$ & $\mathrm{x}$ & $\mathrm{x}$ & / & / & $\mathrm{x}$ & $\mathrm{x}$ & / & $\mathrm{x}$ & 7 \\
\hline & $\begin{array}{l}\text { - Helps to do school } \\
\text { work if needed. }\end{array}$ & $\mathrm{x}$ & $\mathrm{x}$ & $\mathrm{x}$ & / & $\mathrm{x}$ & $\mathrm{x}$ & $\mathrm{x}$ & / & $\mathrm{x}$ & $\mathrm{x}$ & $\mathrm{x}$ & $\mathrm{X}$ & $\mathrm{x}$ & / & $\mathrm{x}$ & $\mathrm{x}$ & 3 \\
\hline & $\begin{array}{l}\quad \text { Buying training } \\
\text { books or Malay Language } \\
\text { reading materials. }\end{array}$ & I & I & $\mathrm{X}$ & I & I & $\mathrm{x}$ & I & $\mathrm{x}$ & I & I & $\mathrm{X}$ & $\mathrm{X}$ & $\mathrm{X}$ & $\mathrm{X}$ & $\mathrm{X}$ & $\mathrm{x}$ & 7 \\
\hline & $\begin{array}{l}\text { - Sending to tuition } \\
\text { classes. }\end{array}$ & $\mathrm{x}$ & $\mathrm{X}$ & $\mathrm{X}$ & $\mathrm{X}$ & $\mathrm{X}$ & $\mathrm{x}$ & $\mathrm{X}$ & $\mathrm{X}$ & $\mathrm{x}$ & $\mathrm{x}$ & $\mathrm{X}$ & $\mathrm{X}$ & $\mathrm{X}$ & $\mathrm{X}$ & $\mathrm{X}$ & $\mathrm{X}$ & 0 \\
\hline
\end{tabular}




\begin{tabular}{|c|c|c|c|c|c|c|c|c|c|c|c|c|c|c|c|c|c|c|}
\hline \multirow[t]{6}{*}{ No } & \multirow{4}{*}{$\begin{array}{c}\text { Creating a Malay } \\
\text { Language Environment }\end{array}$} & \multicolumn{16}{|c|}{ Student Study Participants (SSP) } & \multirow{4}{*}{ Total } \\
\hline & & \multicolumn{8}{|c|}{ SMKA } & \multicolumn{8}{|c|}{ SMKB } & \\
\hline & & $\mathbf{0}$ & $\mathbf{0}$ & $\mathbf{0}$ & $\mathbf{0}$ & $\mathbf{0}$ & $\mathbf{0}$ & $\mathbf{0}$ & 0 & $\mathbf{0}$ & 1 & 1 & 1 & 1 & 1 & 1 & 1 & \\
\hline & & 1 & 2 & 3 & 4 & 5 & 6 & 7 & 8 & 9 & $\mathbf{0}$ & 1 & 2 & 3 & 4 & 5 & 6 & \\
\hline & $\begin{array}{l}\text { - Threatening } \\
\text { parents will impose } \\
\text { punishment if they do not } \\
\text { learn Malay Language. }\end{array}$ & $\mathrm{x}$ & $\mathrm{x}$ & $\mathrm{x}$ & $\mathrm{x}$ & $\mathrm{X}$ & $\mathrm{x}$ & $\mathrm{x}$ & $\mathrm{x}$ & $\mathrm{x}$ & / & $\mathrm{x}$ & $\mathrm{x}$ & $\mathrm{x}$ & $\mathrm{x}$ & $\mathrm{X}$ & $\mathrm{x}$ & 1 \\
\hline & $\begin{array}{l}\text { - Parents do not } \\
\text { know their child's Malay } \\
\text { Language lessons. }\end{array}$ & $\mathrm{x}$ & $\mathrm{x}$ & $\mathrm{x}$ & $\mathrm{x}$ & $\mathrm{x}$ & $\mathrm{x}$ & $\mathrm{x}$ & $\mathrm{x}$ & $\mathrm{x}$ & $\mathrm{x}$ & $\mathrm{X}$ & $\mathrm{x}$ & / & $\mathrm{x}$ & $\mathrm{x}$ & / & 2 \\
\hline \multirow[t]{3}{*}{8} & \multicolumn{17}{|c|}{ Parents support Malay Language activities in schools: } & \\
\hline & - $\quad$ Yes & $\mathrm{x}$ & $\mathrm{x}$ & $\mathrm{x}$ & $\mathrm{x}$ & $\mathrm{x}$ & $\mathrm{x}$ & $\mathrm{x}$ & $\mathrm{X}$ & $\mathrm{X}$ & $\mathrm{X}$ & $\mathrm{x}$ & $\mathrm{x}$ & $\mathrm{x}$ & $\mathrm{x}$ & $\mathrm{X}$ & $\mathrm{x}$ & 0 \\
\hline & No & 1 & I & 1 & 1 & 1 & 1 & I & 1 & I & I & I & I & I & I & I & I & 16 \\
\hline \multirow[t]{4}{*}{9} & \multicolumn{17}{|c|}{ The summary of the B40 pupil's Malay Language environment is: } & \\
\hline & $\begin{array}{l}\text { SSP requires } \\
\text { mastery of reading and } \\
\text { writing skills. }\end{array}$ & / & / & / & / & / & / & / & / & / & / & / & / & / & / & I & I & 16 \\
\hline & $\begin{array}{l}\text { Parents help create } \\
\text { a positive environment to } \\
\text { help kids master reading } \\
\text { and writing skills at home. }\end{array}$ & I & $\mathrm{X}$ & $\mathrm{x}$ & $\mathrm{X}$ & $\mathrm{X}$ & $\mathrm{X}$ & $\mathrm{X}$ & $\mathrm{X}$ & $\mathrm{X}$ & I & $\mathrm{X}$ & $\mathrm{X}$ & $\mathrm{X}$ & $\mathrm{X}$ & $\mathrm{X}$ & $\mathrm{X}$ & 2 \\
\hline & $\begin{array}{l}\text { Parents support } \\
\text { the activities that the school } \\
\text { runs to help children master } \\
\text { reading and writing skills. }\end{array}$ & $\mathrm{x}$ & $\mathrm{X}$ & $\mathrm{X}$ & $\mathrm{X}$ & $\mathrm{X}$ & $\mathrm{X}$ & $\mathrm{X}$ & $\mathrm{X}$ & $\mathrm{X}$ & $\mathrm{X}$ & $\mathrm{X}$ & $\mathrm{X}$ & $\mathrm{X}$ & $\mathrm{X}$ & $\mathrm{X}$ & $\mathrm{X}$ & 0 \\
\hline
\end{tabular}

For B40 Malay students, there are two Malay B40 students who also did not favour Malay Language subjects, namely SSP10 and SSP11, while SSP09, SSP12 and SSP16 favoured learning Malay Language. In other words, favouring or dislike of learning Malay Language is among the causes that cause them to be weak and less smooth reading and writing in Malay B40 students, especially among Chinese B40 students.

The poor mastery of Malay Language in reading and writing B40 students has to do with the practice of communicating in Malay. Through interviews, all 16 B40 students said that they always speak or use Malay Language only in class. Outside of class or at home, they more speak in their native language. Based on interviews with Chinese SSP01 and SSP05 India clearly shows that the use of Malay Language is more in class or during school hours. There is no malay communication at home, especially among the B40 students of Chinese and Indians. In the event of a conversation or speech in MalayMalay Language, the B40 students of the Chinese and Indians speak a lot or communicate with different teachers and classmates of the nation. For B40 Malay students, they speak Malay Language at home or outside class because they are their native language.

Do you always speak Malay Language at home, in class, outside the classroom? I used to speak Malay Language at home with my father but not frequently. If in my class I only spoke Malay Language with Malay teachers and friends only. I would use English if I spoke to an Indian friend and I used Chinese in case of speaking with a Chinese friend. (SSP01/TB/Line 4-11)

Do you always speak Malay at home, in the classroom, outside the classroom? Not. I always speak Tamil especially at home and outside the classroom. (SSP05/TB/Lines 3-5)

B40 students of either Malays, Chinese, or Indians state that their parents have encouraged and supported their children (SSP) to speak and master Malay Language. Their parents do not prohibit or prohibit them from speaking Malay Language. Among the ways that these B40 parents use are:

1. Parents advise to study hard for Malay Language subjects.

2. Helps make school work if needed.

3. Purchase Malay Language exercise books or Malay Language reading materials

4. Sending children to Malay Language tuition classes

5. Parents will threatening their kids to give punishments if they do not learn Malay Language well.

Do you always speak Malay Language at home, in class, outside the classroom? Yes I always speak English. Do your parents prohibit for you to speak Malay Language at home? Not BM is my family's speech language at home. (SSP11/TB/Line 5-9) 
Do your parents prohibit for you to speak Malay Language at home? My mother didn't prohibit me speaking Malay Language at home but my mother never spoke Malay Language while we were at home so I also never spoke Malay at my house. SSP04/TB/Line 10-14)

Do your parents always encourage you to master The Malay Language well? There are, mothers and fathers advise me to learn Malay Language because Malay Language is important to get an SPM certificate. (SSP08/TB/Line 41-44)

Do your parents always encourage you to master The Malay Language well? There are, mothers and fathers advise me to learn Malay because BM is important to get an SPM certificate. (SSP08/TB/Line 41-44)

As a summary, in creating a Malay Language environment, the skills of reading and writing B40 students can be increased if parents play a role in helping their children master reading and writing skills. B40 parents can help Malay Language teachers and schools overcome reading and writing B40 students who do not know or are less skilled at reading and writing in a way:

1. Helps create a positive environment to help kids master reading and writing skills at home.

2. To provide support for the activities that the school runs to help children master reading and writing skills.

\section{Building Confidence to Use Malay Language}

Table 4 discusses the confidence to dare to use Malay Language in school, outside classes or at home among B40 students. Through interviews conducted, these B40 students have reading skills and write levels 1, 2 and 3 based on MoE scale (2019). Level 1 Very limited, Level 2 Limited and Level 3 Satisfactory proves that B40 students who become SSPs are students who have trouble reading and writing Malay Language. Only one (SSP12 Malay B40 students) achieved Level 4 Good in reading and writing skills. This proves that the participants selected were study participants who had problems reading and writing Malay Language. All SSP B40 Chinese and Indians were identified as having problems reading and writing where 9 B40 students (7 Chinese B40 students and 2 B40 Indian students) had problems reading and writing Malay Language. Although B40 Malay students had trouble reading and writing, but all of them (4 Malay B40 students) had Level 3 reading skills writing, which is satisfactory. This means that B40 Malay students who become SSPs are having problems reading and writing, which is less seamless reading and writing skills in Malay Language education.

TABLE 4. Build confidence to use Malay language that can help master reading skills and write B40 students

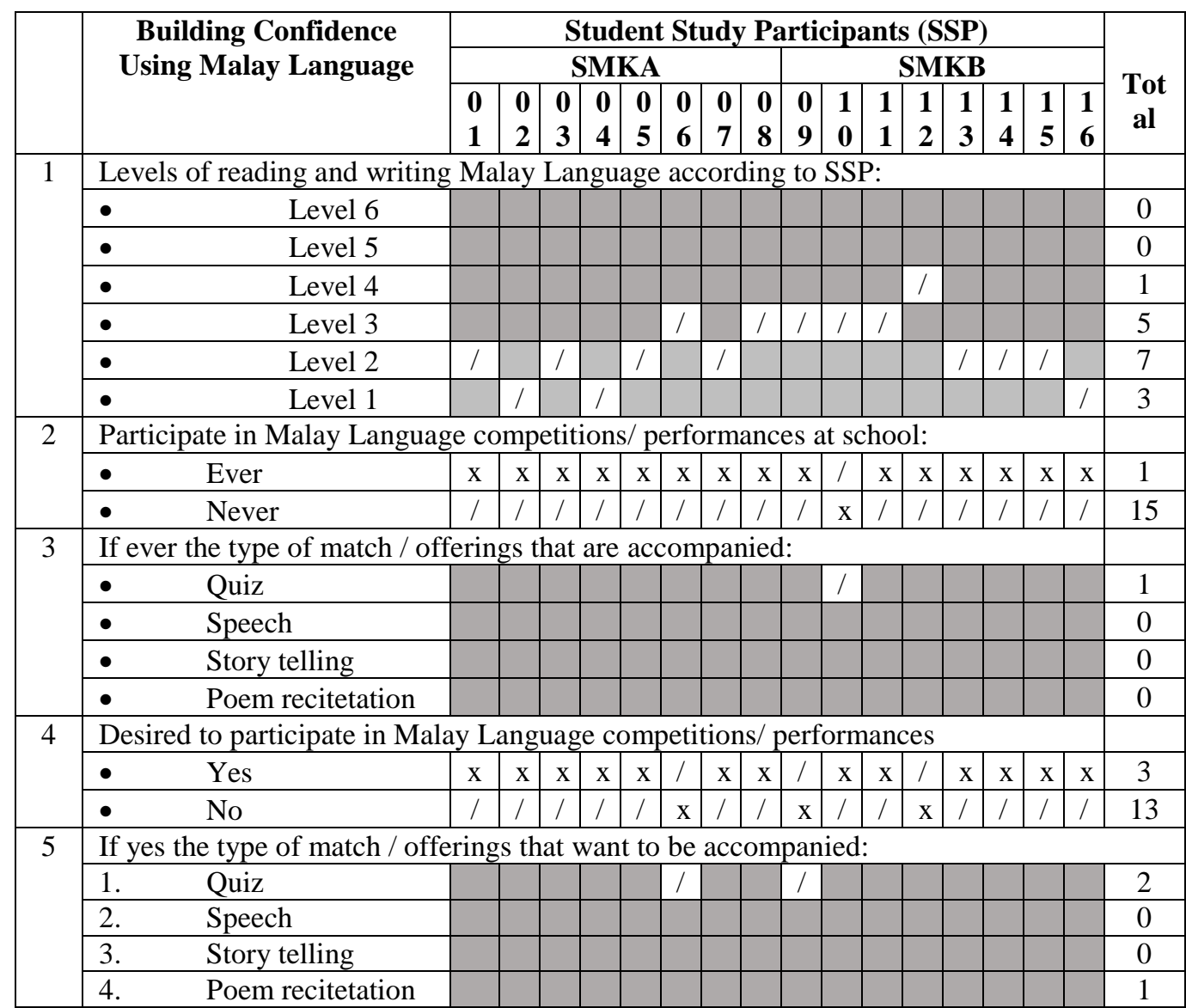




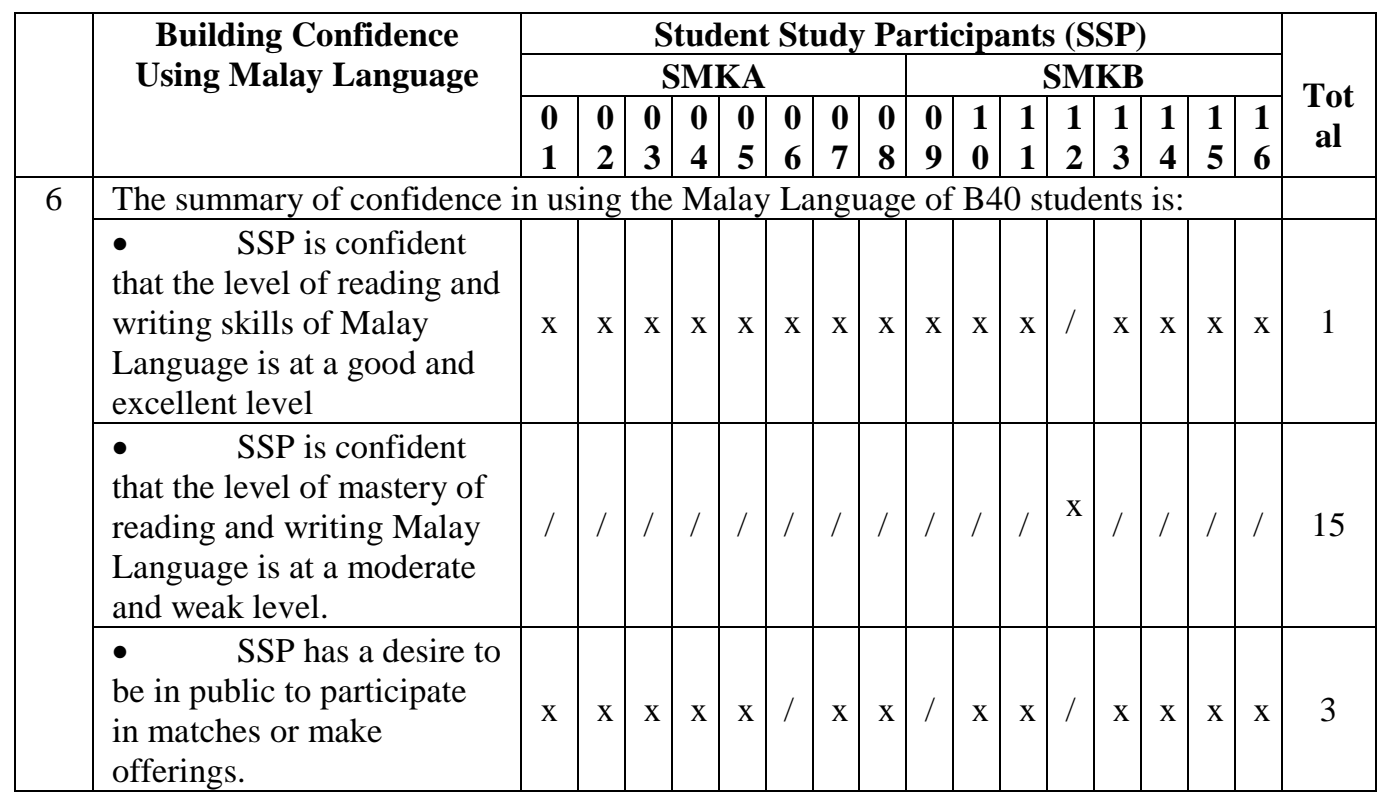

The disadvantages of reading and writing these B40 students also have something to do with their involvement in language activities in schools. A total of 15 of the 16 SSPs interviewed stated they had never joined any language activities in school. If anyone participates in it is by SSP10 (Malay B40 students) by participating in the quiz only.

Are you always participating in Malay Language activities conducted by the teacher? I've been following language quizzes activities that teachers have ever conducted but actually I'm quite excited to use a laptop in a computer lab not because I like to participate in the quiz. (SSP10/TB/Line 21-24)

As a summary, the B40 students of the Malays, Chinese and Indians still weakened their confidence in using Malay Language in school. These beliefs can be measured in terms of reading and writing levels and level of engagement in accompriarched language activity where:

1. The level of mastery of reading skills and writing Malay students B40 is at a moderate and weak level.

2. B40 students are not involved in every language activity in school.

\section{Involvement in Self Development and Learning}

Table 5 discusses involvement in the self-development and learning of the Malay Language of B40 students interviewed. This engagement helps to improve the reading and writing skills of B40 students, namely:

1. There are Malay Language reading materials at home.

2. Just read the Malay Language reading material if you are working on homework or examination.

TABLE 5. Involvement in self-development and learning that can help master reading and writing B40 students

\begin{tabular}{|c|c|c|c|c|c|c|c|c|c|c|c|c|c|c|c|c|c|c|}
\hline \multirow{4}{*}{$\begin{array}{l}\mathbf{N} \\
\mathbf{0}\end{array}$} & \multirow{4}{*}{$\begin{array}{c}\text { Participation in Malay } \\
\text { Language Self } \\
\text { Development and } \\
\text { Learning }\end{array}$} & \multicolumn{16}{|c|}{ Student Study Participants (SSP) } & \multirow{4}{*}{$\begin{array}{c}\text { Tot } \\
\text { al }\end{array}$} \\
\hline & & \multicolumn{8}{|c|}{ SMKA } & \multicolumn{8}{|c|}{ SMKB } & \\
\hline & & $\mathbf{0}$ & $\mathbf{0}$ & $\mathbf{0}$ & $\mathbf{0}$ & $\mathbf{0}$ & 0 & 0 & 0 & 0 & 1 & $\mathbf{1}$ & 1 & 1 & & 1 & & \\
\hline & & $\mathbf{1}$ & 2 & 3 & 4 & 5 & 6 & 7 & 8 & 9 & $\mathbf{0}$ & $\mathbf{1}$ & 2 & 3 & 4 & 5 & 6 & \\
\hline \multirow[t]{3}{*}{1} & \multicolumn{17}{|c|}{ There are Malay Language reading materials at home: } & \\
\hline & - $\quad$ Yes & 1 & $\mathrm{x}$ & $\mathrm{x}$ & 1 & 1 & I & / & / & I & I & I & $x$ & $\mathrm{x}$ & / & $\mathrm{X}$ & $\mathrm{x}$ & 10 \\
\hline & No & X & / & / & $\mathrm{x}$ & $\mathrm{x}$ & X & X & X & X & $X$ & X & / & / & $\mathrm{x}$ & / & / & 6 \\
\hline \multirow[t]{7}{*}{2} & \multicolumn{17}{|c|}{ Frequency of using Malay Language reading materials at home: } & \\
\hline & - $\quad$ Every day & $\mathrm{x}$ & $\mathrm{x}$ & $\mathrm{x}$ & $\mathrm{x}$ & $\mathrm{x}$ & $\mathrm{X}$ & $\mathrm{x}$ & $\mathrm{x}$ & $\mathrm{x}$ & $\mathrm{X}$ & $\mathrm{X}$ & $\mathrm{X}$ & $\mathrm{x}$ & $\mathrm{x}$ & $\mathrm{x}$ & $\mathrm{x}$ & 0 \\
\hline & 2 to 4 per week & & $\mathrm{X}$ & $\mathrm{X}$ & $\mathrm{x}$ & $\mathrm{x}$ & $\mathrm{X}$ & X & $\mathrm{X}$ & X & $X$ & $X$ & X & $\mathrm{x}$ & $\mathrm{x}$ & $\mathrm{x}$ & $\mathrm{x}$ & 0 \\
\hline & $\begin{array}{ll}\bullet & \text { Onceevery } 2 \\
\text { weeks } & \end{array}$ & $\mathrm{X}$ & $\mathrm{x}$ & $x$ & $\mathrm{x}$ & $\mathrm{x}$ & $\mathrm{x}$ & $\mathrm{x}$ & $\mathrm{X}$ & / & $\mathrm{X}$ & $\mathrm{X}$ & $\mathrm{X}$ & $x$ & $\mathrm{x}$ & $x$ & $\mathrm{x}$ & 1 \\
\hline & Oncea month & 7 & $\mathrm{X}$ & $\mathrm{X}$ & $x$ & $x$ & $X$ & $X$ & $\mathrm{X}$ & X & $X$ & $X$ & X & $x$ & $\mathrm{X}$ & $\mathrm{X}$ & $\mathrm{x}$ & 1 \\
\hline & Veryrarely & $X$ & $\mathrm{X}$ & $\mathrm{X}$ & 1 & 1 & 1 & 1 & $x$ & $x$ & I & $\mathrm{X}$ & $\mathrm{X}$ & $x$ & $\mathrm{x}$ & $\mathrm{x}$ & $\mathrm{x}$ & 5 \\
\hline & $\begin{array}{l}\text { Only read the } \\
\text { Malay Language }\end{array}$ & I & / & / & / & / & I & I & I & I & I & I & 7 & / & / & / & / & 16 \\
\hline
\end{tabular}




\begin{tabular}{|c|c|c|c|c|c|c|c|c|c|c|c|c|c|c|c|c|c|c|}
\hline \multirow{5}{*}{$\begin{array}{l}\mathbf{N} \\
\mathbf{o}\end{array}$} & \multirow{4}{*}{$\begin{array}{c}\text { Participation in Malay } \\
\text { Language Self } \\
\text { Development and } \\
\text { Learning }\end{array}$} & \multicolumn{16}{|c|}{ Student Study Participants (SSP) } & \multirow{4}{*}{$\begin{array}{c}\text { Tot } \\
\text { al }\end{array}$} \\
\hline & & \multicolumn{8}{|c|}{ SMKA } & \multicolumn{8}{|c|}{ SMKB } & \\
\hline & & 0 & 0 & $\mathbf{0}$ & $\mathbf{0}$ & $\mathbf{0}$ & 0 & 0 & 0 & 0 & 1 & 1 & 1 & 1 & 1 & 1 & 1 & \\
\hline & & 1 & 2 & 3 & 4 & 5 & 6 & 7 & 8 & 9 & $\mathbf{0}$ & 1 & 2 & 3 & 4 & 5 & 6 & \\
\hline & $\begin{array}{l}\text { material while doing } \\
\text { homework or prepare for } \\
\text { exam. }\end{array}$ & & & & & & & & & & & & & & & & & \\
\hline \multirow[t]{5}{*}{3} & \multicolumn{17}{|c|}{ Television broadcasts that are preferred to watch at home: } & \\
\hline & $\begin{array}{l}\bullet \quad \text { Broadcast using } \\
\text { Malay Languge. }\end{array}$ & $\mathrm{x}$ & $\mathrm{X}$ & $\mathrm{x}$ & $\mathrm{x}$ & I & / & / & / & I & I & I & / & $\mathrm{x}$ & / & $\mathrm{X}$ & I & 10 \\
\hline & $\begin{array}{l}-\quad \text { Broadcast using } \\
\text { Chinese Languge. }\end{array}$ & I & I & I & I & $\mathrm{X}$ & $\mathrm{X}$ & $X$ & $\mathrm{X}$ & $\mathrm{X}$ & $\mathrm{X}$ & $\mathrm{X}$ & $\mathrm{X}$ & / & / & I & $\mathrm{X}$ & 7 \\
\hline & $\begin{array}{l}\text { - } \quad \text { Broadcast using } \\
\text { Tamil Languge. }\end{array}$ & $\mathrm{X}$ & $\mathrm{X}$ & $\mathrm{x}$ & $\mathrm{X}$ & / & / & $X$ & / & $X$ & $X$ & $\mathrm{X}$ & $\mathrm{X}$ & $\mathrm{x}$ & $\mathrm{X}$ & $\mathrm{X}$ & $\mathrm{x}$ & 3 \\
\hline & $\begin{array}{l}\bullet \quad \text { Broadcast using } \\
\text { English Languge. }\end{array}$ & $\mathrm{X}$ & $\mathrm{X}$ & $\mathrm{X}$ & $\mathrm{X}$ & $\mathrm{X}$ & $\mathrm{X}$ & $\mathrm{X}$ & / & $\mathrm{X}$ & $\mathrm{X}$ & $\mathrm{X}$ & $\mathrm{X}$ & $\mathrm{x}$ & $\mathrm{X}$ & $\mathrm{X}$ & $\mathrm{x}$ & 1 \\
\hline \multirow[t]{3}{*}{4} & \multicolumn{17}{|c|}{ Comfortably watch broadcast using Malay Language at home: } & \\
\hline & $\bullet \quad$ Yes & $\mathrm{x}$ & $\mathrm{x}$ & $\mathrm{x}$ & $\mathrm{x}$ & I & I & / & / & I & I & I & / & $\mathrm{x}$ & I & $\mathrm{x}$ & I & 10 \\
\hline & No & 1 & 1 & 1 & 1 & $\mathrm{X}$ & $\mathrm{x}$ & $\mathrm{X}$ & $\mathrm{X}$ & $\mathrm{X}$ & $\mathrm{X}$ & $\mathrm{X}$ & $\mathrm{x}$ & 1 & $\mathrm{x}$ & I & $\mathrm{x}$ & 6 \\
\hline \multirow[t]{5}{*}{5} & \multicolumn{17}{|c|}{ Languages used on social media: } & \\
\hline & $\begin{array}{l}\bullet \quad \text { Malay } \\
\text { Language. }\end{array}$ & $\mathrm{x}$ & $\mathrm{x}$ & $\mathrm{x}$ & $\mathrm{x}$ & I & / & / & $\mathrm{x}$ & / & / & / & / & $\mathrm{x}$ & $\mathrm{x}$ & $\mathrm{x}$ & / & 8 \\
\hline & $\begin{array}{l}\text { Chinese } \\
\text { Language }\end{array}$ & / & / & / & / & $\mathrm{X}$ & $\mathrm{X}$ & $\mathrm{X}$ & $\mathrm{X}$ & $\mathrm{X}$ & $\mathrm{X}$ & $\mathrm{X}$ & $\mathrm{X}$ & / & / & / & $\mathrm{X}$ & 7 \\
\hline & - $\quad$ Tamil Language & $\mathrm{X}$ & $\mathrm{X}$ & $\mathrm{x}$ & $\mathrm{x}$ & / & I & I & / & $\mathrm{X}$ & $\mathrm{X}$ & $\mathrm{X}$ & $\mathrm{X}$ & $\mathrm{x}$ & $\mathrm{x}$ & $\mathrm{x}$ & $\mathrm{x}$ & 4 \\
\hline & $\begin{array}{l}\bullet \quad \text { English } \\
\text { Language }\end{array}$ & l & $\mathrm{x}$ & $\mathrm{x}$ & $\mathrm{x}$ & $\mathrm{X}$ & $\mathrm{X}$ & $\mathrm{X}$ & / & $\mathrm{X}$ & $\mathrm{X}$ & $\mathrm{X}$ & $\mathrm{X}$ & $\mathrm{x}$ & $\mathrm{x}$ & $\mathrm{x}$ & $\mathrm{X}$ & 2 \\
\hline \multirow[t]{3}{*}{6} & \multirow{4}{*}{\multicolumn{17}{|c|}{$\begin{array}{l}\text { The ability to read and write in Malay Language helped SSP lerarned well: } \\
\begin{array}{|c|c|c|c|c|c|c|c|c|c|c|c|c|c|c|c|c}\text { Yes } & / & \mathrm{x} & / & / & / & / & / & / & / & / & / & / & / & / & / & / \\
\text { No } & \mathrm{x} & / & \mathrm{x} & \mathrm{x} & \mathrm{x} & \mathrm{x} & \mathrm{x} & \mathrm{x} & \mathrm{x} & \mathrm{x} & \mathrm{x} & \mathrm{x} & \mathrm{x} & \mathrm{x} & \mathrm{x} & \mathrm{x} \\
\text { Preferred teaching methods to } & \text { improve the } \\
\text { skills in Malay: }\end{array} \\
\text { - }\end{array}$}} & \\
\hline & & & & & & & & & & & & & & & & & & 15 \\
\hline & & & & & & & & & & & & & & & & & & 1 \\
\hline \multirow[t]{6}{*}{7} & & & & & & & & & & & & & & & & & & \\
\hline & - $\quad$ Group activities & $\mathrm{x}$ & $\mathrm{x}$ & $\mathrm{x}$ & $\mathrm{x}$ & $\mathrm{x}$ & $\mathrm{x}$ & $\mathrm{x}$ & 1 & $\mathrm{x}$ & $\mathrm{x}$ & $\mathrm{x}$ & $\mathrm{x}$ & $\mathrm{x}$ & $\mathrm{x}$ & $\mathrm{x}$ & $\mathrm{x}$ & 1 \\
\hline & $\begin{array}{l}\text { Teachers talk } \\
\text { and write up front. }\end{array}$ & / & / & / & l & I & I & / & / & / & / & / & / & / & $\mathrm{X}$ & $\mathrm{x}$ & $\mathrm{x}$ & 13 \\
\hline & $\begin{array}{l}\text { - Like group } \\
\text { activities if guided. }\end{array}$ & / & $\mathrm{x}$ & $\mathrm{X}$ & $\mathrm{x}$ & $\mathrm{X}$ & $\mathrm{X}$ & $\mathrm{X}$ & $\mathrm{X}$ & $\mathrm{X}$ & $\mathrm{X}$ & $\mathrm{X}$ & $\mathrm{X}$ & $\mathrm{x}$ & $\mathrm{x}$ & $\mathrm{x}$ & $\mathrm{x}$ & 1 \\
\hline & $\begin{array}{l}\text { Teachers } \\
\text { provide examination's } \\
\text { practice questions/ fill in } \\
\text { the blank/ objective } \\
\text { questions. }\end{array}$ & $\mathrm{X}$ & $\mathrm{X}$ & $\mathrm{X}$ & $\mathrm{X}$ & I & $\mathrm{X}$ & $\mathrm{X}$ & $\mathrm{X}$ & I & $\mathrm{X}$ & $\mathrm{X}$ & I & $\mathrm{x}$ & $\mathrm{X}$ & I & I & 5 \\
\hline & $\begin{array}{l}\text { - Teachers don't } \\
\text { give much exercise or } \\
\text { homework. }\end{array}$ & $\mathrm{X}$ & $\mathrm{X}$ & $\mathrm{X}$ & $\mathrm{X}$ & $\mathrm{X}$ & $\mathrm{X}$ & $\mathrm{X}$ & $\mathrm{X}$ & $X$ & $X$ & $X$ & $\mathrm{X}$ & $\mathrm{x}$ & I & I & $\mathrm{X}$ & 2 \\
\hline 8 & \multicolumn{17}{|c|}{$\begin{array}{l}\text { Summary of involvement in the self-development and learning of B40 students } \\
\text { is: }\end{array}$} & \\
\hline & $\begin{array}{l}\quad \text { SSP less } \\
\text { reading materials in } \\
\text { Malay Language. }\end{array}$ & I & I & I & I & / & / & I & I & I & I & I & I & I & I & I & I & 16 \\
\hline & $\begin{array}{l}\text { - SSP watches } \\
\text { television broadcasts by } \\
\text { native language. }\end{array}$ & $\mathrm{X}$ & $\mathrm{X}$ & $\mathrm{X}$ & $\mathrm{X}$ & / & / & I & I & I & I & I & I & $\mathrm{x}$ & I & $\mathrm{X}$ & I & 10 \\
\hline & $\begin{array}{l}\text { - SSP uses } \\
\text { mother language as a } \\
\text { medium of intermediary } \\
\text { on social media. }\end{array}$ & $\mathrm{X}$ & $\mathrm{X}$ & $\mathrm{X}$ & $\mathrm{X}$ & I & I & I & $\mathrm{X}$ & I & I & I & I & $\mathrm{x}$ & $\mathrm{X}$ & $\mathrm{X}$ & I & 8 \\
\hline & - $\quad$ SSP is aware & I & $\mathrm{X}$ & I & I & 1 & 1 & I & / & / & I & I & I & I & I & I & I & 15 \\
\hline
\end{tabular}




\begin{tabular}{|c|c|c|c|c|c|c|c|c|c|c|c|c|c|c|c|c|c|c|}
\hline \multirow{5}{*}{$\begin{array}{l}\mathbf{N} \\
\mathbf{0}\end{array}$} & \multirow{4}{*}{$\begin{array}{c}\text { Participation in Malay } \\
\text { Language Self } \\
\text { Development and } \\
\text { Learning }\end{array}$} & \multicolumn{16}{|c|}{ Student Study Participants (SSP) } & \multirow{4}{*}{$\begin{array}{c}\text { Tot } \\
\text { al }\end{array}$} \\
\hline & & \multicolumn{8}{|c|}{ SMKA } & \multicolumn{8}{|c|}{ SMKB } & \\
\hline & & 0 & 0 & $\mathbf{0}$ & $\mathbf{0}$ & $\mathbf{0}$ & ( & 0 & 0 & 0 & 1 & 1 & 1 & $\mathbf{1}$ & 1 & 1 & 1 & \\
\hline & & 1 & 2 & 3 & 4 & 5 & 6 & 7 & 8 & 9 & $\mathbf{0}$ & 1 & 2 & 3 & 4 & 5 & 6 & \\
\hline & $\begin{array}{l}\text { that the mastery of the } \\
\text { Malay Language can } \\
\text { help them to master other } \\
\text { subjects. }\end{array}$ & & & & & & & & & & & & & & & & & \\
\hline
\end{tabular}

The frequency of reading Malay reading materials is more widely used or practiced by B40 students of Indians and Malays. B40 Chinese students do not read Malay Language reading materials. Besides their parents who did not buy Malay Language reading materials, B40 Chinese students were more comfortable communicating in Chinese (Mandarin). They also did not watch Malay Language-speaking television broadcasts instead watching Chinese-speaking broadcasts. This is one of the factors that caused chinese B40 students to not know and lack of smooth reading and writing Malay Language. The following interview supports the Chinese B40 pupil's statement.

Are there Malay Language reading materials at home? At home I didn't have a direct Malay Language reading material. While watching television broadcasts or which shows are your choice? I only watch Chinese and Hong Kong television broadcasts including current news. I've never watched a Malay-speaking show. When using social media what languages do you use? I use Chinese while typing messages when interacting with friends and family. (SSPO3/TB/Line 23-29)

Ifanything,howoftendoyoureadthosematerials? IrarelyreadMalay Language reading material at home. I justreadwhentheteacheraskedtodothejob. Whilewatchingwhichtelevisionbroadcastsareyourchoice? Iwatchedalot ofChinesebroadcastsbutmyMalay Language-speaking network watched Malaymovies, Ilovedghoststories. Whenusingsocialmediawhatlanguagesdoyouuse? IalwaysuseChinesewhencommunicatingwithfriendsthroughsoc ialmedia.(SSP13/TB/Line26-31)

This is in contrast to B40 Indian students who love watching Malay Language speaking television broadcasts. Indian B40 students also communicate on social media using Malay Language. For that reason, the Malay Language of B40 students is much better than the Chinese B40 students. The B40 Indian pupil statement can be seen in the following interview:

While watching which television broadcasts are your choice? I love watching sports broadcasts. When using social media what languages do you use? I use social media in Malay. I use Whatsapp. (SSP05/TB/Line 23-25)

While watching which television broadcasts are your choice? I've always chosen english-speaking networks and very few watch broadcasts in Malay Language. Me and my family always watch TV2. When using social media what languages do you use? I always use Malay Language and English when communicating with friends through social media. (SSP08/TB/Line 23-29)

The B40 students acknowledge that reading and writing abilities in Malay Language can help them learn well. A total of 15 out of 16 SSP people agreed. Nevertheless, they expect more teachers to explain in front of classes. Both Malay, Chinese or Indian B40 students, 13 SSPs prefer their Malay Language teachers to speak and write on blackboards. In this way, they were able to write Malay Language well. These B40 students don't like to learn groups, instead they prefer to learn themselves. They also don't like Malay Language teachers who:

1. Loves to be angry at them.

2. Give a lot of practice in the classroom or homework.

3. Make group activities where they prefer to learn themselves.

4. Call the student to the front of the class to answer the practice.

The opinion of these B40 students has little impact on their reading and writing skills. This B40 pupil statement gets from the following interviews:

In your opinion, how do I teach the Malay Language you want? I like it if the teacher gives questions such as exams while teaching. I would prefer that the teacher talks up front and gives me training. I don't like it if the teacher makes group activities because the class condition will be noisy. (SSP09/TB/Line 40-44)

In your opinion, how do I teach the Malay Language you want? I would prefer to have the teacher speak and write in front of the class because in a way I am easier to understand. (SSP03/TB/Line 33-36) 
In your opinion, how do I teach the Malay Languageyou want? I would prefer that the teacher talks up front and gives me training. (SSP06/TB/Line 31-33)

On the other hand, the B40 students were less comprehensively involved in every language organised by the school. Hence, involvement in the self-development and learning of Malay Language by B40 students of Malays, Chinese and Indians is due to:

1. Less read Malay Language books.

2. Watch television broadcasts according to their respective native languages.

3. Using the mother language of B40 students as a medium of intermediary on social media.

4. Recognizing that the mastery of the Malay Language can help them to master other subjects.

\section{DISCUSSION}

Reading and writing are two skills that can determine whether a person can read and write well or not. This is not the same as oral skills (listening and speaking). Oral skills cannot measure a person already mastering reading and writing skills or not. Therefore, reading and writing skills need to be mastered, as well as oral skills. In the context of malay teaching and learning, reading and writing skills are important dominated by each students. Regardless of gender, race and cognitive level of students, reading and writing skills can determine whether the student can acquire good Malay Language achievements or not. This is because reading skills can help students understand what is read well. With a good understanding of what is read, students will be able to write well about what they read. In other words, the skills of reading and writing are intertepeable. Without understanding what is read, of course one cannot write well what is read.

\section{Level of Mastery of Students Reading Skills B40 Malays, Chinese and Indians}

The failure of students to master reading and writing skills smoothly needs to be addressed immediately. The problem of mastering reading and writing skills has greatly influenced the achievements of students in Malay Language learning. In the study, there were many B40 students, especially B40 Chinese and Indian students not understanding what was read based on the Reading Test (Understanding) given to them. Their level of understanding is very limited and limited so that they cannot answer the Malay Language Reading Test well. The findings are in line with Abdul Rasid (2011) study which found students were facing reading skills problems. Students fail to understand the information contained in the text read. In fact, students also fail to understand the meaning of sentences in quotes or reading text.

The study, conducted by Chew (2016) supports the findings of this study. The Chee study found ethnic Chinese students were weak in reading skills and even writing. Likewise, a study conducted by Mohd Fuad (2018) who found Indian students had difficulties and confusion in learning Malay Language so that they were difficult to master the Malay Language well. This is the truth where most primary and secondary school students consist of B40 students (Mohd Nazri (2014).

Mohd Nazri's statement (2014) was in line with the findings of a study in which most students who did not know reading or lacking were fluent or smooth reading came from the B40 family. These B4 students do not receive quality education with various factors. Among them are poverty factors and financial factors for parents of B40. The parents of these B40 students are on average low-income students. Parents of these B40 students cannot help their children in mastering reading skills well. This resulted in parents of B40 students regardless of being able to provide educational facilities for their children such as purchasing learning materials, sending children to tuition classes etc. The Tamam (2011) study found parents were less striving to help their children master reading skills. This also applies to the parents of the B40 students. Parents of B40 students are busier looking for sustenance and handing over the affairs of educating their children to teachers and schools.

Apart from the financial factors and poverty of parents, the failure of B40 students of Malays, Chinese and Indians also stemmed from the attitude of B40 students themselves. The attitude of B40 students regardless of Malay, Chinese and Indian lazy to learn, not focused when studying and so on are among the causes that the B40 students are still weak and fail to master reading skills well. According to Tamam (2011), the problem of weak students mastered reading skills among others due to the factors of the students themselves. Students are also not in earnest to read. Students who don't like reading cause them slow to master reading skills. Sabar (2007) found that non-Malay students had no reading habits and lack of satisfaction in reading skills. The findings of Tamam (2011) and Sabar (2007) are in line with studies of study in which B40 students are mainly Chinese B40 students and do not like reading.

In a study conducted by KPM (2016b) found two-thirds of B40 students were lowly educated in academia. The attitude, motivational and behavioral factors of B40 students greatly influenced their achievements including in Malay Language learning. This MoE study is in line with the study of surveyers where all B40 students surveyed are low-performance students. They are not only weak in reading skills, but they also don't have a learning culture. Their learning motivation is low. Their behaviour in the classroom was also less satisfactory. They were not only disoriented with the Malay Language teachers and other teachers who taught him, but also lazy learned and made noise in the classroom. This is in contrast to B40 students of Malays and Indians who are interested in learning even though they do not know or are less smooth reading skills. 
The study also found that B40 students were more dependent on Malay Language teachers. For example, they don't like teachers giving a lot of training in class or homework training. They prefer Malay Language teachers who do not provide school training or homework training. Such attitudes cause them to be weak in learning, including not mastering reading skills. According to Sabar (2007), students who are weak, especially non-Malay students do not have good reading habits. They do not like reading and thus affect the achievements in Malay Language learning. In this study, the study found that B40 students did not like reading and more dependent on teachers to learn Malay Language.

In the study also found that B40 students did not help schools and Malay Language teachers in helping their children master reading skills. Parents of B40 students have more to hand over their children's learning to Malay Language teachers and schools. The parents of B40 students, especially parents of Chinese students discourage their children speaking Malay Language, do not buy Malay Language reading materials and consider Malay Language insofant to be mastered. The findings of this study are in line with the Tamam study (2011) which found parents were less striving to help their children master reading skills. Zarinah et al. (2018) study found that most B40 parents faced stress in life until they neglected their children's education. In this study, this study clearly shows the parents of B40 students have no effort to help their children master reading skills. However, the findings of the study contrary to the study of Zulkifli et al. (2011). Zulkifli et al has conducted research among the poor parents in Selangor. The results of their study found even poor parents, but parents provided support and involvement in helping their children in learning. Parents' involvement in learning children helps their children in their studies even if parents from poor families.

In conclusion, the students of B40 are Malay, Chinese and Indians who were participants of this study are students who did not know or less smoothly read. Based on the Reading Test (Understanding) made, the scale of reading most of them is very limited and limited. Only two have satisfactory reading levels, and they are malay B40 students. These Chinese and Indian B40 students on average still do not know or have less smooth reading. Taking it easy, uninterested in learning and not having a learning culture (KPM 2016a) caused B40 students to still be low in Malay Language achievement.

\section{Level of Mastery of Skills in Writing B40 Students of Malays, Chinese and Indians}

Writing skills are the most difficult language skills mastered by students, especially among students who learn Malay Language as a second language. B40 students of Chinese and Indians who became participants of this study were those who studied Malay Language as a second language. Most of these Chinese and Indian B40 students are weakened to their writing skills. This is said to be because the writing skills involve complex processes and require a systematic level of mastery (Che Zanariah and Fadzilah 2011). Not only that, writing skills are very synonymous with the ability of students to write gramatist words or verses, while complying with grammar laws. This statement is in line with Zamri's opinion (2014), writing activities have a close relationship with speaking and reading skills. As a result, something that is expressed orally and read cannot be moved in the form of writing if the pupil does not master the skills of writing well.

In the study, almost 81 percent or 13 B40 students were unable to write or very limited malay writing skills. Through written tests conducted, these B40 students have their skill levels of writing very limited and limited. Most of them are Chinese B40 students and B40 Indian students who have trouble writing Malay Language. The findings of this study are in line with the Norsimah et al. (2012) study, which found that most non-Malay students had moderate levels in Malay writing. This is the truth because through interviews with Malay Language teachers state the B40 students they teach weak in writing skills. B40 students don't know what's written even if they understand the text they read.

Besides that, the problem of not mastering the writing skills of B40 students can be increased if parents play a role in helping their children master the writing skills. B40 parents should help Malay Language teachers and schools overcome the problem of writing B40 students who do not know or are less adept at writing. The findings showed that parents of B40 students lacked efforts to create an environment to help their children master writing skills. This is very pronounced to the parents of Chinese B40 students. The parents of B40 Chinese students do not create much malay environment at home. This has influenced the Malay language of their children. Nevertheless, the parents of B40 students of The Malays and Indians have plenty to support the activities that the school runs to help the children master the writing skills. The findings of the study parallel to the study of Kanammah et al (2013) which found the influence of families, especially parents greatly influenced their children's learning methods. The support and involvement of parents is important to help their children master a subject and thus enhance their achievements. The same goes for research

The B40 students of The Malays, Chinese and Indians still weaken their confidence in using Malay Language in school. This confidence can be measured in terms of writing levels as well as the level of involvement in language activities participated by B40 students where the level of skills of writing Malay Language students B40 is at a moderate and weak level. Most B40 students are not involved in each language activity held by the school. The B40 students were less comprehensively involved in each language organised by the school. Hence, the involvement in the self-development and learning of Malay Language by B40 students of Malays, Chinese and Indians was due to their lack of reading of Malay Language reading materials, watching television 
broadcasts according to their native language, using their native language as an intermediate medium on social media. The findings in line with the $\operatorname{KPM}(2011)$ study also supported the findings of studies where the financial factors of parents had led parents to be unable to provide learning facilities for their children. As a result, their children dropped out of their studies or low academic achievements, including Malay Language learning. However, the findings of this study contrary to the findings of the Zulkifli et al. (2011) study, which found that most of the poor parents comprising B40 families were involved in their children's learning activities.

In conclusion, the weakness of B40 students of Malays, Chinese and Indians in mastering writing skills is not due to poverty factors, but also due to other factors such as environmental influence, peer influence, teacher teaching method, etc. This corresponds to the Tamam (2011) which states that the problem of reading and writing primary school students among others is due to the following six factors, namely the pupil's own factor, pupil psychology, teacher's teaching method, environment, teaching time and reading textbooks used.

\section{CONCLUSION}

Reading skills are basic skills that students need to master before mastering writing skills. Students who do not master reading skills will have difficulty understanding what is read. As a result, students know or are unable to write well. In fact, some of them do not know what is read and written. Writing skills are a combination of various speaking competencies to build discourse or writing text based on certain regulations. Hence, students should be proficient in this skill as it involves many everyday activities in life. Teachers, on the other hand, play a big role in ensuring students can master these skills.

Students from B40 families are students who are often low-educated, living in rural areas or city pings, many siblings, non-educated and working labourers, living in small houses or cheap homes etc. In conclusion, reading and writing problems are a problem that is hard to dominate by B40 family students. Therefore, the findings can be used as a source of reference for stakeholders studying education among B40 students of various races in Malaysia.

\section{Acknowledgement}

Thanks to the Faculty of Education, UKM for providing the Fpend Research Fund with research code: GG2020-083 untill this article is successfully published.

\section{REFERENCE}

1. Abdul Rasid Jamian \& Zulkafli Abu Zarin. (2008). Keupayaan kemahiran membaca dan menulis Bahasa Melayu murid sekolah rendah kebangsaan luar bandar. Konvensyen Pendidikan Nasional 2008. Anjuran Universiti Pendidikan Sultan Idris, 2 - 4 Jun 2008.

2. Abdul Rasid Jamian, Norhashimah Hashim \& Shamsudin Othman. (2012). Multimedia interaktif mempertingkatkan pembelajaran kemahiran membaca murid-murid Probim. Jurnal Pendidikan Bahasa Melayu, 2 (2): 46-53.

3. Abdul Rasid Jamian. (2011). Permasalahan kemahiran membaca dan menulis Bahasa Melayu muridmurid sekolah rendah di luar bandar. Jurnal Pendidikan Bahasa Melayu, 1 (1): 1-12.

4. Abdul Rasid Jamian. (2012). Multimedia interaktif mempertingkatkan kemahiran membaca murid-murid PROBIM. Jurnal Pendidikan Bahasa Melayu, 2 (2): 46-53.

5. Ary. D., Jacobs, L.C., Sorenson, C. \& Razavieh, A. (2006). Introduction to Research in Education. Belmont: Wadsworth.

6. Celinea anak Lasan \& Zamri Mahamod. (2018). Amalan Membaca Timbal Balik Murid Etnik Bidayuh. Bangi: Penerbit Universiti Kebangsaan Malaysia.

7. Celinea anak Lasan. (2018). Amalan pembelajaran reciprocal (timbal balik) dalam kemahiran membaca Bahasa Melayu dalam kalangan murid peribumi Bidayuh. Tesis Doktor Falsafah. Fakulti Pendidikan, Universiti Kebangsaan Malaysia.

8. Che Zanariah Che Hassan \& Fadzilah Abd Rahman. (2011). Pelaksanaan pengajaran dan pembelajaran kemahiran menulis di sekolah rendah. Jurnal Pendidikan Bahasa Melayu, 1 (1): 67-87.

9. Chew, Fong Peng. (2016). Masalah pembelajaran Bahasa Melayu dalam kalangan murid Cina sekolah rendah. Jurnal Pendidikan Bahasa Melayu, 6 (2): 10-22.

10. Chua, Yan Piaw. (2014). Asas Statistik Penyelidikan. Edisi Ke-2. Kuala Lumpur: McGraw Hill (M) Sdn. Bhd.

11. Creswell, J.W. (2008). Educational Research: Planning, Conducting and Evaluating Quantitative and Qualitative Research. $2^{\text {nd }}$ Edition. New Jersey: Pearson Education.

12. Jabatan Perangkaan Malaysia. (2017). Pendapatan Garis Kemiskinan. Putrajaya: Jabatan Perdana Menteri. 
13. Kammaah a/p Manukaram, Melissan Ng Lee Yen Abdullah \& Shahizan Hassan. (2013). Pengaruh faktor keluarga terhadap pembelajaran regulasi kendiri murid sekolah rendah. Malaysia Journal of Learning and Instruction, 10 (9): 179-201.

14. Kementerian Pendidikan Malaysia. (2011). Kajian Perbandingan Pencapaian Akademik Pelajar Lelaki dan Perempuan Sekolah Menengah..Putrajaya: Bahagian Perancangan dan Penyelidikan Dasar Pendidikan.

15. Kementerian Pendidikan Malaysia. (2013). Pelan Pembangunan Pendidikan Malaysia 2013-2025. Putrajaya: Bahagian Pembangunan Kurikulum.

16. Kementerian Pendidikan Malaysia. (2016a). Kurikulum Standard Sekolah Menengah. Putrajaya: Bahagian Pembangunan Kurikulum.

17. Kementerian Pendidikan Malaysia. (2016b). Kajian Murid Lemah Pencapaian Akademik. Putrajaya: Bahagian Perancangan dan Penyelidikan Dasar Pendidikan.

18. Kementerian Pendidikan Malaysia. (2019). Dokumen Standard Kurikulum dan Pentaksiran: Darjah 1 hingga 6. Putrajaya: Bahagian Pembangunan Kurikulum.

19. Marshall, C. \& Rosmann, G.B. (2006). Designing Qualitative Research. $4^{\text {th }}$ Edition. Thousand Oaks, CA: Sage Publications.

20. Merriam, S.B. (2001). Qualitative Research and Case Study Applications in Education: Revised and Expanded from Case Study Research in Education. San Francisco: Josey-Bass Publisher.

21. Mohd Fuad Abd. Rahman. (2018). Aplikasi, sikap dan masalah guru dan murid di SJK Tamil terhadap pembelajaran dan pemudacaraan Bahasa Melayu berkonsepkan flipped classroom. Kertas Projek Sarjana Pendidikan. Fakulti Pendidikan, Universiti Kebangsaan Malaysia.

22. Mohd Nazri Abdul Rahman. (2014). Pembangunan model home schooling berasaskan nilai dan amalan masyarakat bagi kanak-kanak Orang Asli. Tesis Dr. Falsafah. Fakulti Pendidikan, Universiti Malaya.

23. Nor Hamizah Abd. Rahman. (2016). Faktor demografi dan sosioekonomi kumpulan B40 dalam pemilikan takaful keluarga/insuran hayat. Proceeding of the 2 nd International Conference on Economics and Banking 2016 (2ndICEB) pada 24-25 Mei.

24. Norsimah Mat Awal, Nadzrah Abu Bakar \&Nor Hashimah Jalaluddin. (2012). Pembelajaran Bahasa Melayu sebagai bahasa kedua: pengungkapan idea dalam penulisan pelajar sekolah menengah di Malaysia. Jurnal Melayu, 9: 227-240.

25. Sabar Hj. Mohd. (2007). Tabait membaca dalam kalangan murid sekolah luar bandar. Kertas Projek Sarjana Pendidikan. Fakulti Pendidikan, Universiti Kebangsaan Malaysia.

26. Tamam Timbang, Zamri Mahamod \& Afendi Hamat. (2011). Faktor dan kesan masalah membaca dalam kalangan murid sekolah rendah kerajaan di Brunei Darussalam. Jurnal Pendidikan Bahasa Melayu, 1 (1): 89-107.

27. Tamam Timbang. (2011). Kemahiran membaca dalam kalangan murid sekolah rendah kerajaan di Brunei Darussalam: Satu kajian kualitatif. Tesis Sarjana Pendidikan. Fakulti Pendidikan, Universiti Kebangsaan Malaysia.

28. Yahya Othman \& Dk. Suzanawaty Pg. Osman. (2014). Keupayaan menguasai kemahiran menulis pembelajaran berasaskan Projek Nilam dalam penulisan berbentuk risalah di sekolah rendah. Jurnal Pendidikan Bahasa Melayu, 4 (1): 19-29.

29. Yin. R.K. (2012). Applications of Case Study Research. 3th Edition. Thousand Oaks, California: Sage Publication.

30. Zamri Mahamod. (2014). Inovasi P\&P dalam Pendidikan Bahasa Melayu. Cetakan Ketiga. Tanjung Malim: Penerbit Universiti Pendidikan Sultan Idris.

31. Zamri Mahamod \& Anita Abdul Rahaman. (2020). Profesion Keguruan dan Pembangunan Insan. Bangi: Penerbitan Universiti Kebangsaan Malaysia.

32. Zarinah Arshat, Farah Syuhada Pai \& Zanariah Ismail. (2018). Keluarga B40: Tekanan dan kekuatan. Journal of Advanced Research in Social anda Behavioural Sciences, 10 (1): 91-102.

33. Zulkifli Abd. Hamid, Jamilah Othman, Aminah Ahmad \& Ismi Arif Ismail. (2011). Hubungan antara penglibatan ibu bapa dan pencapaian akademik pelajar miskin di negeri Selangor. Journal of Islamic and Arabic Education, 3 (2): 31-40. 